\title{
PODEJMOWAĆ KOLEJNE WYZWANIA
}

\section{Adolf Wysocki}

Konsul Honorowy Finlandii w Szczecinie

\section{Szanowny Panie Profesorze,}

W publikacji Uniwersytetu Szczecińskiego z okazji Jubileuszu 75-lecia urodzin Profesora w roku 2002 (A. Wysocki, Skojarzenia absolwenta..., w: Trzymajmy się Morza, Wydawnictwo US, 2002, s. 63), formułując życzenia na 2013 rok, napisałem:

W roku 2013, jako już emerytowany żeglugowiec, chciałbym zasiąść wspólnie z Panem Profesorem - w kawiarence na wyspie Bielawa, vis-á-vis Wałów Chrobrego, obserwując cumujące tu jachty, podążające w dół Odry liczne barki i rzesze turystów przybywających do pobliskiego Muzeum morskiego w którym, pośród eksponatów, mogliby znaleźć informacje nie tylko o dawnej, ale i obecnej potędze Polski morskiej. (...) Jest jeszcze długa droga do przebycia, aby te marzenia się mogły się spełnić, ale - żywię wciąż taką nadzieję - my Polacy, przestaniemy uczyć się na błędach, trwać w swarach i sporach, a spożytkujemy nauki wyniesione z uniwersytetów!

Słowa te, nadal pozostają moim aktualnym życzeniem, jakkolwiek zmuszony jestem wprowadzić drobną poprawkę odnośnie do emerytury. Z przywilejów emerytalnych korzystam dopiero od marca 2016 roku.

\section{KOCHAJ SWOJĄ PRACĘ I CIESZ SIĘ ŻYCIEM}

Richard Branson w swojej autobiografii (R. Branson, Kroki w nieznane. Autobiografia, Wydawnictwo Natalis, 2008) zawarł wiele prawd o sobie, w tym, poza umiłowaniem pracy, wymienił umiejętność cieszenia się życiem.

Zastanawiając się nad tym, jakie motto życiowe przyświeca Profesorowi Gronowskiemu dochodzę do wniosku, że z pewnością kocha to, co robi, bo inaczej nie prowadziłby wykładów przez ponad 60 lat.

Dążenie do założonych w życiu celów polega na nieustannym wysiłku odnajdywania właściwej drogi. A wybór drogi wymaga odpowiedniej wiedzy. Profesor, jako wykładowca i pedagog, dzielił się tą wiedzą również ze swoimi byłymi studentami - jako współorganizator i uczestnik Sejmików Morskich, konferencji, seminariów i sympozjów naukowych. Nie do przecenienia pozostaje fakt wypromowania wielu doktorów - praktyków z branży morskiej. 


\section{PODEJMOWAĆ KOLEJNE WYZWANIA}

Dążyć do bezstronnej oceny bieżących wydarzeń i włączać się w procesy zarządzania. W przypadku Profesora, było to zarządzanie wydziałem, następnie uczelnią, pełniąc funkcję rektora Politechniki Szczecińskiej w jakże trudnych latach, na początku dekady lat osiemdziesiątych ubiegłego stulecia.

To zachęta Profesora (Profesorowi się nie odmawia...) spowodowała, że zdecydowałem się prowadzić wykłady dla studentów IV roku kierunku Ekonomika Transportu Morskiego na Wydziale Inżynieryjno-Ekonomicznym US z przedmiotu eksploatacja handlowa statku morskiego w semestrze zimowym 1989/1990.

Podjęta następnie próba uzyskania zgody Rady Wydziału na wprowadzenie wykładu fakultatywnego na WZiEU US z problematyki ekonomiczno-społecznej krajów afrykańskich (w ramach zakładu Gospodarki Światowej i Transportu Morskiego) zakończyła się niepowodzeniem.

Jedyną satysfakcją i potwierdzeniem potencjalnego zainteresowania przedmiotem była liczna obecność studentów i kadry na wykładzie pilotażowym na temat moich ponad 30-letnich (wówczas) doświadczeń w kontaktach Szczecina z krajami Afryki zachodniej. Wykład zawierał prezentację i oryginalne materiały zebrane podczas zarządzania Linią Zachodnioafrykańską (w Polskich Liniach Oceanicznych i następnie Euroafrica Linie Żeglugowe Spółka z o.o. w Szczecinie).

Wizja pogłębionych kontaktów gospodarczych z krajami afrykańskimi jest obecnie realizowana między innymi przez ministerstwo spraw zagranicznych dzięki projektowi „Go Africa”.

\section{ZAUFANIE I PRZYJAŹŃ}

Decyzja o ubieganiu się o przyjęcie na Studium Doktoranckie na Wydziale Inżynieryjno-Ekonomicznym Politechniki Szczecińskiej (w 1976 r.) była podjęta w dość trudnym dla mnie okresie (obciążenie obowiązkami rodzinnymi i zawodowymi). Po rozmowie z Profesorem, zdecydowałem się na złożenie dokumentów, dołączając 10- stronicowe opracowanie Nowoczesne technologie przewozu w transporcie morskim na przykładzie Polskich Linii Oceanicznych.

Niestety termin egzaminu ustnego zbiegał się w czasie z moją zagraniczną podróżą służbową. Pod moją nieobecność, Profesor przedstawił mnie jako jednego ze swoich absolwentów, któremu można zaufać i warto dać szansę kontynuacji studiów.

„Życie pełne pasji, entuzjazmu i pewnej dozy humoru tworzy otoczenie sprzyjające rozwojowi innych osób, wyzwala emocje" - cytat z książki Bransona jest wart przytoczenia również w kontekście mojej znajomości ze śp. prof. dr hab. kpt. ż.w. Leszkiem Plewińskim (zmarłym w sierpniu 2012 r.), poznanym na Studium Doktoranckim w 1976 roku. Wzajemny szacunek i przyjaźń oraz podobne zainteresowania stanowiły o naszej kilkudziesięcioletniej przyjaźni. Znajomość z Leszkiem Plewińskim zaczęła się na seminarium u Profesora Franciszka Gronowskiego. Było to zdarzenie dla mnie początkowo dość niefortunne, gdyż po zaprezentowaniu pierwotnej wersji pierwszego rozdziału mojej rozprawy doktorskiej, który napisałem nie mając wystarczającej ilości czasu, tekst ten napotkał druzgocącą krytykę. Osobą, która szczególnie dosadnie wypowiedziała się na temat zaprezentowanego tekstu był właśnie Leszek. Milczenie Profesora Gronowskiego, uśmiech na twarzy, odbierałem, jako największe upokorzenie, postanawiając, że... to się więcej nie powtórzy. 
Profesor był jednym z trzech recenzentów mojej rozprawy doktorskiej, której promotorem był profesor Ignacy Chrzanowski (obronionej 16 czerwca 1981 r.).

Z kolegą Leszkiem odbywaliśmy konsultacje, debatując o wielu istotnych sprawach, dotyczących zarówno jego działalności w Akademii Morskiej, polskiej i światowej gospodarki morskiej, jak i bieżących problemów zarządzania tonażem Euroafrica Linie Żeglugowe.

W 2008 roku wspólnie z ówczesnym Zarządem Euroafrica linie Żeglugowe Spółka z o.o., podjęliśmy się organizacji Sympozjum „,Safe Shipping on the Baltic Sea”, którego pierwsza edycja odbyła się w Szczecinie a kolejne (naprzemiennie) w Gdańsku i Szczecinie.

Do grona współorganizatorów tego, jakże ważnego przedsięwzięcia, włączyły się także $e^{1}$ Związek Armatorów Polskich, Biuro Promocji Żeglugi Morskiej Bliskiego Zasięgu, Polski Rejestr Statków SA oraz administracja morska kraju. Od roku 2011 tematyka sympozjum została włączona, jako jeden z paneli, do programu Kongresu Morskiego w Szczecinie.

\section{LEGISLACJA MORSKA A PRAKTYKA}

Nowe strategie zarządzania majątkiem o wielkiej wartości w warunkach postępującej globalizacji, wyścig techniczny i technologiczny, komputeryzacja i cyfryzacja, to tylko niektóre elementy specyfiki transportu morskiego, funkcjonującego na podstawie konwencji i przepisów międzynarodowych.

Marine Propulsion Industry Survey przeprowadzony we współpracy z ExxonMobil, w odpowiedzi na pytanie: „Jak dalece jesteś przekonany o tym, że $\mathrm{IMO}^{2}$ reprezentuje interesy Armatorów?" wykazał, że o wypełnianiu tej misji jest przekonanych zaledwie 19\% respondentów przy ponad 40\% odpowiedziach negatywnych (What do shipowners think of IMO, ,Marine Propulsion \& Auxiliary Machinery" 2016, April/May, s. 5).

Jeżeli większość armatorów wyraża negatywną opinię o pracy IMO, to powstaje pytanie, kto reprezentuje ich w IMO? - bowiem każde państwo członkowskie desygnuje tam swoich przedstawicieli do komitetów stałych i grup roboczych.

W ostatnim 25-leciu powstało wiele organizacji i stowarzyszeń pozarządowych w Polsce, w pracach których bierze udział wielu ekspertów i wybitnych przedstawicieli branży morskiej. Uczestniczyli oni w konsultacjach na etapie stanowienia prawa oraz opiniowaniu projektów rozporządzeń zarówno krajowych, jak i międzynarodowych.

1 Obszar Morza Bałtyckiego z wyłączeniem wód pod zwierzchnictwem i jurysdykcją Federacji Rosyjskiej jest zakwalifikowany przez IMO od 2006 r., jako Szczególnie Wrażliwy Obszar Morski (ang. Particularly Sensitive Sea Area).

2 Międzynarodowa Organizacja Morska (ang. International Maritime Organisation - IMO) z siedzibą w Londynie powstała 17.03.1959r. pod nazwą Intergovernmental Maritime Consultative Organisation. Od 22.05.1982 r. pod obecną nazwą. Wyspecjalizowana agencja ONZ zajmująca się bezpieczeństwem i ochroną żeglugi morskiej oraz zapobieganiem zanieczyszczeniom za statków na morzu. Według stanu na rok 2015 jej członkami jest 171 państw i trzy państwa w charakterze członków stowarzyszonych. 40 organizacji międzyrządowych posiada umowy o współpracy z IMO zaś 61 organizacji pozarządowych ma przy niej status doradczy. Źródło: www.imo.org./eng. 


\section{SUKCESIE DECYDUJĄ LUDZIE}

Z konsultacji z Profesorem Gronowskim wyniosłem wiele prawd, jak chociażby tę, wypływającą z przysłowia Vox audita perit littera scripta manet ${ }^{3}$, co staram się stosować w praktyce. Dowodem na to jest kilkadziesiąt publikacji, prezentacje na konferencjach, sympozjach i seminariach, zarówno w kraju, jak i zagranicą.

W artykule All change, please? - The need for innovation and a new perspective (por. The Annual Bulletin: „Baltic Rim Economies”, z. 5, z 17.12.2015, University of Turku, Pan-European Institute of the Turku School of Economics, Finland) zamieściłem następujące stwierdzenie: „obecne pokolenie, poprzez podejmowane inicjatywy, musi potwierdzić zrozumienie swojej odpowiedzialności za przyszłość Regionu Morza Bałtyckiego”. Co więcej, świadomość tego faktu winna również skutkować zwiększoną aktywnością i jeszcze większą otwartością w kontaktach z otoczeniem zewnętrznym, zarówno ze strony centrum, władz samorządowych, organizacji pozarządowych oraz środowiska akademickiego.

Szanowny Panie Profesorze!

W podzięce za życzliwe i inspirujące konsultacje oraz oznaki przyjaźni wraz z życzeniami Ad multos Annos!

Pozostaję z wyrazami najwyższego uszanowania

3 Z j. łacińskiego (w przekładzie na język polski: „Słowa sq ulotne, myśli zapisane pozostaja”- AW). 